\title{
A Contrastive Analysis of the Translation of Irony in the Holy Qur'an: the Translations of Mualawi Sher Ali and Yusuf Ali
}

\author{
Ibrahim I.I. Najjar ${ }^{1}$ \\ University of Malaya
}

\begin{abstract}
:
This paper is carried to find out if the translation of irony from Arabic," the Holy Quran" into English might change the intended meaning. To tackle this problem, the study ventures into a contrastive analysis with reference to a number of linguistic and non-linguistic devices and concepts. It concentrates on the interpretation and the linguistic realization of irony in both languages. The study takes the view that ironic devices are the foundation of the structural development of the texts in question. To demonstrate this, the speech act and conversational theories have been used. The interaction between the ironic devices and the text development constitute a framework for the overall rhetorical meaning of the text. Thus, contrastive analysis and comparative stylistics analysis have been implemented. A thorough contrastive analysis is made of when translating irony from Arabic into English using two versions of translations; the translations of Mualawi Sher Ali and Yusuf Ali.It is found that the meaning of the ironic lexical words have been to a high degree maintained in the process of translation. Similarities and differences between both texts have also been found. In addition, both translators have implemented the literal translation strategy to render the examples of irony.
\end{abstract}

Keywords: Irony, Meaning, Translation, Literal, Quran, Strategy

\section{INTRODUCTION}

Irony is meant to be applied to human behavior. It is taken from the Greek word "eironeia" which means "dissimulation". Irony is a controversial concept in the study of language. Many authors and scholars tried to accurately define irony; however, they did not succeed. Mateo (1995) stated that the old concept said about irony "saying one thing and meaning another" is no longer accurate portrayal of the complex techniques used by writers to create irony. This is confirmed by Simpson (2011) who stated that "irony has a frequent and common definition: "sayingwhat is contrary to what is meant."Irony is such a highly rhetorical and elusive tool that it is difficult to define in terms of its interpretation, let alone style and language (Chakhachiro, 2011). Newmark (1993: 132) also added that irony is "the most serious and powerful weapon insatirical comedy and farce, particularly when used to expose pomposity and deceit or to deflate self-importance."

Ruiz-Moneva (2001) cited Lukács and said that he (1920) sees in irony a possible way to reconcile the dialectical opposition between the subjective and the objective, even though it has been claimed that in his later works he came to question the extent to which it can be said to reflect reality.

\section{LITERATURE REVIEW}

Scholars have provided different kinds of irony, but the most three known ones are situational, verbal and dramatic irony. Situational irony is looked at as the difference between the outcome and the expectations made about a situation. As for verbal irony, it is the opposite of a said utterance or speech. Dramatic irony is the awareness of something by the readers or the audiences which the main character is not aware of.

Ruiz-Moneva(2001) mentioned that irony ceases to be approached in rhetorical terms as meaning the opposite orsomething other than what is said. Irony may create a tension among all possible differentmeanings, without pointing at any of them, and on the whole any possible misunderstandingsor ambiguities may be left unresolved.

${ }^{1}$ Corresponding Author: inajjar87@yahoo.com 


\section{American Research Journal of English and Literature, Volume 1, Issue 5, 2015}

ISSN 2378-9026

Attempting to describe the variable features which affect the quality of irony, Muecke recognises the necessity for ironists "to break with advantage the rules of art" (1982: 52) in order to enhance irony. Therefore, he gives four principles for a successful irony based on his observation that "A rhetorically effective, an aesthetically pleasing, or simply a striking irony owes its success... largely to one or more of a small number of principles and factors" (ibid: 52).

These principles are: 1) the principle of economy, which implies the use of few signals. It is used in parody, advice and encouragement, the rhetorical question and other ironical tactics. 2) The principle of high contrast, which takes place when "there is a disparity between what might be expected and what actually happened" (ibid: 53), or when there is antithesis, semotactic anomalies or internal contradiction. 3) The position of the audience, particularly in the theatre where "the quality of the irony depends very much on whether the audience already knows the outcome or true state of affairs or learns of these only when the victim of irony+ learns" (ibid: 54); and 4) the topic. This last factor or principle relates to the importance of emotions in generating and enhancing both the observer's feelings toward the victim or the topic of the irony and the reader's awareness and appreciation of the irony on an equal footing, among "the areas in which most emotional capital is invested: religion, love, morality, politics, and history" (ibid: 55). Although only the fourth principle above seems to touch on the function of irony, it is fair to say that the first three principles are integral to get to grips with ironic messages.

\section{RESEARCH METHOD}

This is a qualitative descripted study as it aimed to find whether the meaning of Irony in Quran has been changed or maintained while translating into English. The researcher has employed conversational analysis and comparative stylistic approaches in the analysis. A total number of 8 examples were taken from the holy Quran and their translations into English by Mualawi Sher Ali and Yusuf Ali.

\section{DAta ANALYSiS}

Ayah 1:

ويقتلون الذين يامرون بالقسط من الناس,فبشر هم بعذاب اليم

\section{Mualawi Translation}

And seek to kill such men as enjoin equity-announce to them a painful punishment.

\section{Yusuf Translation}

And slay those who teach just dealing with mankind, announce to them agrievous penalty.

Looking at both translations, it is noticed that the two translations offer a near meaning of the lexical word "فبشر هم" since the word "announce" does not carry the exact meaning of the Arabic one. In terms of translation, the first translator has used literal translation to render the word "فبشر هم" as "announce to them". It is also noticed that the

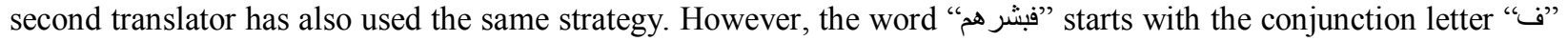
which is missed in both translations. Syntactically, the two translations do not carry the same structure of the lexical word since the conjunction "ف is missed in the two translations. However, it is acceptable to delete the letter "ف" to come up with a better translation.

Ayah 2:

اكفرنم بعد ايمانكم فذوقو ا العذاب بما كنتم تكفرون

Mualawi Translation

Did you disbelieve after believing? Taste, then, the punishment because you disbelieved.

\section{Yusuf Translation}

"Did ye reject Faith after accepting it? Taste then the penalty for rejectingFaith."

The translators have managed to transfer the intended meaning of the ironic word "فigوق" However, in terms of translation, it is found that both translators have used the verb "taste" to translate the lexical word " but with a clear difference to the structure of the Arabic word.

The two translators have used two translation strategies that are omission and overtranslation. In the process of translation, the " $g$ " mentioned in the Arabic word is deleted by the two translators. This omission does not harm or 
distort the intended meaning of the lexical word. In addition, overtranslation strategy is used. Theconjunction "then" is added in the translation. Semantically and although there is a deletion in the Arabic word, the meaning of the ironic word is maintained.

\section{Ayah 3:}

ونقول ذوقو اعذاب الحريق

\section{Mualawi Translation}

And we shall say: taste ye the punishment of burning.

\section{Yusuf Translation}

And we shall say: "Taste ye the penalty of the Scorching Fire!

Noticing the translations of the ironic word "دوقو", it is found that both translators used the main verb "taste ye" in their translation. Thus, they used the literal translation technique to render the Arabic lexical word. In terms of meaning, using literal translation to render the Arabic ironic lexical word gives the accurate meaning since a direct translation might lead to some changes on the meaning. On the syntactic level, the translations of the Arabic sentence including the ironic word carry the same structure. This is a good translation which keeps the meaning and the structure of the ST.

Ayah 4:

بثر المنافقين بان لهم عذابا اليما

\section{Mualawi Translation}

Give to the hypocrites the tidings that for them is a grievous punishment.

\section{Yusuf Translation}

To the Hypocrites give the glad tidings that there is for them [but] agrievous penalty;-

The irony in both versions has been literally translated but with a slight change on the part of speech. The Arabic lexical word "بشر" is used as a verb. However, if we look at Mualawi’s translation to the ironical lexical word "برر" we find that a noun phrase "the tidings" is used instead of a verb. Likewise, Ali has used a noun phrase "the glad tidings" to render the Arabic ironical word. Semantically, the strategy used by the two translators maintained the meaning of the Arabic lexical word. In addition, the phrase used by Ali, "the glad tidings" is a biblical one which is considered a full equivalent to the Arabic ironical word "بُر".

\section{Ayah 5:}

كتب عليه انه من تو لاه فانه يضلهويهديه الى عذاب السعير

\section{Mualawi Translation}

For whom it is decreed that whosoever makes friend with him, him he will lead astray and will guide himto the punishment of the fire.

\section{Yusuf Translation}

About the [Evil One] it is decreed that whoever turns to him for friendship,him will he lead astray, and he will guide him to the Penalty of the Fire.

Noticing the above examples, the two translations of the Arabic ironic word carry the same meaning. In terms of translation, the two translators have used the same lexical words. Mualawi's translation is a literal one as well as Ali's translation. Syntactically, both translations have to some degree respected the structure of the Arabic sentence. So, if we look at the Ayah above, we find that the ironic word is preceded by the conjunction " $g$ " "and" which is visible in both translations.

However, a small difference appears to be between the two translators. Regarding Ali's translation, it is found that he used the pronoun "he" with the ironic word "guide" to refer to the one who follows Satan. This is not the case of Mualawi' translation where the pronoun "he" is not used with the ironic word "guide". Instead, he used the pronoun "he" at the beginning of the sentence "he will lead astray and will guide him" because he thinks that its meaning is 
implied. Thus he preferred not to repeat the same pronoun two times. On the semantic level, both translations have created an acceptable meaning of the ironic word "ويهديه".

\section{Ayah 6:}

قل تمتع بكفرك قليلا انك من اصحاب النار

\section{Mualawi Translation}

Say, Benefit thyself with disbelief a little while; thou art surely of the inmates of fire

\section{Yusuf Translation}

"Enjoy thy blasphemy for a little while: verily thou art [one] of the Companions of the Fire

Looking at the two translations above, one can notice that the two translators have intended to transfer the intended meaning of the Arabic ironical word. The word "تمنع" is used ironically by Allah and thus it was given equivalent ironical translations. However, in terms of the process of translation, the two translators have used different lexical words to render "تمتع" into English. Thus, Mualawi has used the verb "benefit" while Ali's one is the verb "Enjoy" although Ali's translation is nearer to the meaning of "تمتع" more than Mualawi's one. Syntactically, the two translated versions of the "Ayah" verse respected to some degree the structure of the Arabic sentence which lead to literal translation. In fact, Mualawi's translation fully respects the Arabic sentence.

Ayah 7:

فما أصبر هم على النتّار

\section{Mualawi Translation}

How great is their endurance of the fire!

\section{Yusuf Translation}

Ah! What boldness [They show] for the Fire!

Looking at the example above, one finds that literal translation strategy is used to render the ironic word " "اصبر هم". In terms of translation, the ironic word is translated used different lexical words. Mualawi has used the noun "endurance" while "boldness" has been used by Yusuf. In terms of meaning both translators tried to come up with the exact meaning. But, I think that Mualawi's translation is nearer to the meaning of the Arabic word more than Yusuf's one. On the syntactic level, both translations show to some degree the structure of the Arabic sentence.

\section{Ayah 8:}

فما بكت عليهم السماء و الارض وما كانوا منظرين

\section{Mualawi Translation}

And the heaven and the earth wept not for them, nor were they given a respite. Mualawi

\section{Yusuf Translation}

And neither heaven nor earth shed a tear over them: nor were they given a

respite [again]. Yusuf

Noticing the two translations above, it is found that the translators intended to transfer the intended meaning of the ironic word. In the process of translation, the two translators have employed the literal translation strategy, but with different lexical words in rendering the ironic word. Thus, Mualawi used the verb "wept not", while Ali used "shed a tear". Syntactically, the two translations respected to some extent the structure of the Arabic sentence. To somehow, the meaning of the ironic word is maintained.

\section{CONClusion}

This study aimed at finding whether the translation of irony from Arabic into English will alter the intended meaning. The analysis of eight Qur'anic verses was then followed by a contrastive analysis. This was meant to point out the similarities and differences with a focus on the latter, which I believe, is the crux of any translation study. The analysis has also proved the necessity of the linguistic approach to translating irony from Arabic into English. 


\section{American Research Journal of English and Literature, Volume 1, Issue 5, 2015 ISSN 2378-9026}

Arabic and English texts have shown some similar rhetorical, grammatical and lexical use of devices, text strategies and rhetorical meaning. However, the difference was most clear at the level of textual realization. This was reflected in the discrepancy in the functions and number of devices in both languages. These restrictions are imposed by each language's repertoire and culture. Thus, the cases at hand have shown that the meaning of the irony in both translations has been translated by literal translated in a way to come up with a meaning that is closer to the original one.

\section{REFERENCES}

[1] Ali, A. Y. (1987). The Holy Quran.English Translation.The KingFahd Holy Quran Printing Complex.

[2] Ali, M. S. (2004). The Holy Quran.Arabic Text and English Translation.Islamic International Publication.

[3] Chakhachiro, R. (2011). Translating Irony: An Interdisciplinary Approach with English and Arabic as a Case in Point. Sayyab Books - London Publishing, Distribution \& Translation 3 Lower Teddington Road Kingston upon Thames Surry KT1 4ER London - UK www.sayyab.org.

[4] Luckas, G. (1920). Teoria de la Novela. Barcelona: Edhasa.

[5] Mateo, M. (1995). The Translation of Irony, Meta, XL. 1.

[6] Muecke, D. C. (1982).Irony and the Ironic. London: Methuen.

[7] Newmark, P. (1993). Paragraphs on Translation.Clevedon, Philadelphia, Adelaide: Multilingual Matters Ltd.

[8] Ruiz-Moneva, M. (2001).Towards A Historical Synthesis of the Concept of Irony. ODISEA, N` 1, 2001, P\&GS. 101-120.

[9] Simpson, Paul. (2011). "That's not ironic, that's just stupid: Towards an eclectic account of the discourse of irony." In: Marta Dynel (Ed.), The Pragmatics of Humour across Discourse Domains.Amsterdam, Philadelphia: John Benjamins Publishing Company, 33-50. 